\title{
The precocial mouse, Acomys cahirinus
}

\author{
PETER C. BRUNJES \\ University of Virginia, Charlottesville, Virginia
}

\begin{abstract}
Acomys cahirinus (the "spiny mouse") is a member of the same rodent subfamily as the laboratory rat and mouse. Acomys differs from the laboratory species in several ways, including the fact that it is adapted to a semiarid lifestyle and is born after a long gestation with functional sensory and motor systems. The existing, and quite dispersed, literature on the anatomy, physiology, and behavior of Acomys is briefly reviewed.
\end{abstract}

Acomys cahirinus (called the "spiny mouse" because of the bristly fur covering the rump area) has been used increasingly in psychobiological studies. Acomys, the laboratory rat (Rattus norvegicus), and mouse (Mus musculus) are all members of the same rodent subfamily (Murinae). However, the species have quite different adaptations, physiologies, and behaviors. Perhaps the most striking differences are in their early life histories. Acomys, a precocial mammal, is born after a relatively long gestation ( 39 days using the day after conception as Embryonic Day 1, or E1) with open ears and eyes and quite sophisticated sensory and motor capabilities. The rat and mouse are altricial species: they have shorter gestations ( 22 and 20 days, respectively), larger litter sizes, and are born considerably less mature (Figure 1). The result is an almost unique opportunity to compare developmental processes in phylogenetically related yet ontogenetically divergent species (see Dieterlen, 1963, for a discussion of uniformity in developmental patterns within the mammalian group). Comparative studies of the species might lead to a better understanding of the ways in which developmental patterns can be modified, and how the functional abilities of species change as a result. The following review briefly examines what is known about Acomys on evolutionary, ethological, neurological, and behavioral levels (Dieterlen, 1961; D'Udine \& Alleva, 1988).

\section{PHYLOGENY}

\section{Systematics}

Little agreement exists on the exact number of species contained in the genus Acomys. While Dieterlen (1963) suggested there may be as many as 27 species, Corbet and Hill (1986) listed 9 (A. cahirinus, A. cilicicus, A. louisae, $A$. minous, $A$. russatus, $A$. spinosissimus, $A$. sub-

This research was supported by Grant DC00338 from the National Institutes of Health. Due to the fact that studies employing Acomys are widely spread, references have been undoubtedly (and unfortunately) overlooked. Apologies are extended to anyone whose work has been slighted. Correspondence may be addressed to Peter C. Brunjes, Department of Psychology, 102 Gilmer Hall, University of Virginia, Charlottesville, VA 22903. spinosus, $A$. whitei, and $A$. wilsoni), along with several races and strains. They also pointed out that several of the species are easily confused or have been included as strains of other species. Carleton and Musser (1984) also described nine species. On the other hand, Corbet (1978) claimed that only two species exist: $A$. cahirinus and $A$. russatus, suggesting that most other species are merely variants of $A$. cahirinus, some even with different numbers of chromosomes (Matthey, 1963; Matthey \& Baccar, 1967; Petter \& Roche, 1981).

Acomys is included within the order Rodentia, the infraorder Myomorpha, the superfamily Muroidea (mouselike rodents), and the family Muridae, which contains over 100 genera (Carleton, 1984; Eisenberg, 1981). Acomys, along with the laboratory rat and mouse, is found within the largest subfamily of these, Murinae ("Old World rats and mice'). This fortunate occurrence allows Acomys to be compared with the most intensely studied altricial species available, allowing a wealth of information for comparative studies.

\section{How Closely Related are Acomys and the Laboratory Rat and Mouse?}

Determining exact phylogenetic relationships is a difficult task, especially in groups such as the rodents, which exhibit rapid evolutionary changes with tremendous amounts of convergence and parallelism. The oldest muroid-like fossils (Cricetodon) come from the late Eocene in China (Carleton \& Musser, 1984). Many reports suggest that murine rodents evolved from cricetid stock in the middle Miocene period (approximately 15 million years ago), although considerable differences of opinion appear to exist in the timing of the cricetid/murid separation. Simpson (1959) places the cricetid/murid separation at 10 million years ago. The oldest recognized murid genera, Antemus, was found in Pakistan (Jacobs, 1978). Jacobs suggested that two groups were derived from Antemus; one (Progonomys) gave rise to Mus and the mouselike species, including Acomys. The other (Karnimata) gave rise to many other species, including Rattus. The first migration of the murids was toward Europe and North America as early as the Oligocene period. Murids appear to have invaded Africa later, in the Miocene era (Carleton \& Musser, 1984; Eisenberg, 1981; Flynn, Jacobs, \& 


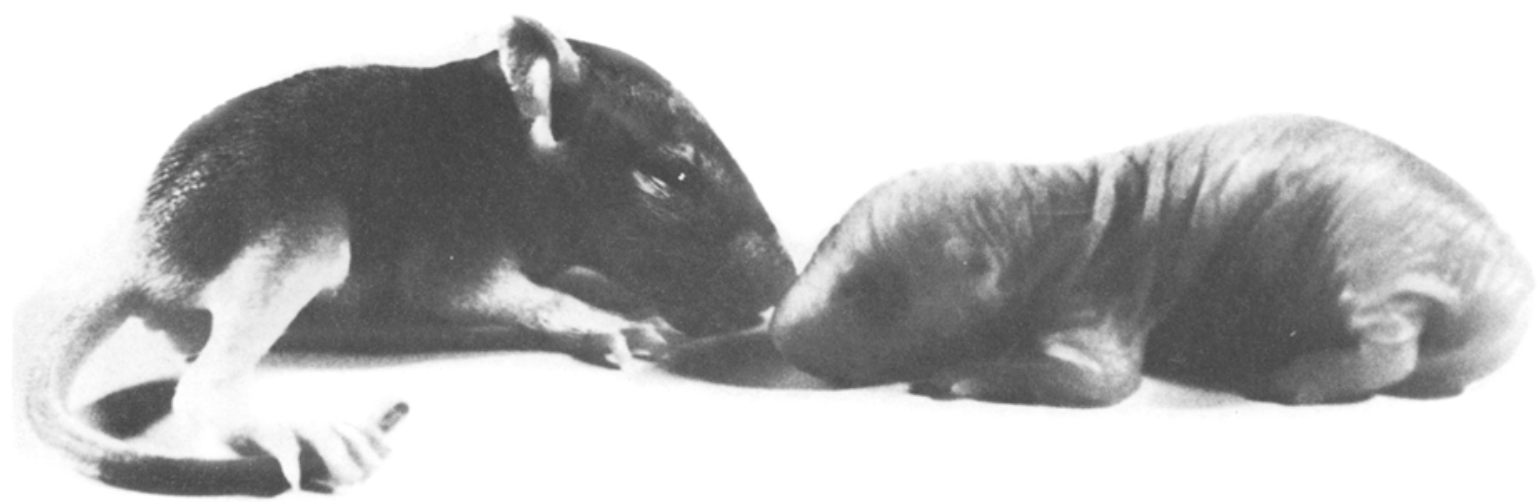

Figure 1. Newborn Acomys cahirinus (left) and laboratory rat (Rattus norvegicus; right).

Lindsay, 1985; Hartenberger, 1985; Lavocat \& Parent, 1985).

Morphological indexes of relatedness have placed Acomys well within the normal ranges of the murids; indeed, Acomys has been called simply a generalized mouse adapted to arid conditions (Kingdon, 1974). Nevertheless, molecular biological approaches to determining species relations (e.g., distance data from immunological, DNA annealing, or protein sequencing) have indicated that $A$. cahirinus is quite divergent from the remainder of the African murids. For example, an albumin immunological comparison suggests that Acomys and Mus are not closely related (Sarich, 1985), and starch gel electrophoresis of 11 protein loci suggests that although the remainder of the African murids may be monophyletic, Acomys diverges substantially (Bonhomme, Iskandar, Thaler, \& Petter, 1985). Therefore, precise relationships between the species are difficult to judge.

\section{GENERAL BIOLOGY}

\section{Distribution and Ecology}

The genus Acomys inhabits western Asia to southern Africa, including the islands of Cyprus and Crete. $A$. $c a-$ hirinus has the widest distribution in the range. Acomys are adapted for an arid lifestyle, living in rocky outcroppings (jebels) in desert regions (Delany \& Happold, 1979; Petter, 1954). A. cahirinus subsists on a mixed diet, including insects, snails, and seeds, and is commensal with man (Vesey-Fitzgerald, 1966). Little is known about their social organization, although they have been reported to live in groups but to not build nests or burrows (Delany \& Happold, 1979). Although commercial suppliers of the species are rare, it is usually not difficult to obtain breeding couples donated by researchers with existing laboratory colonies.

\section{Special Adaptations}

Because of their niche, Acomys have been studied often in order to understand strategies of temperature and water regulation (Borut, Horowitz, \& Castel, 1972; Daily \&
Haines, 1981; Haines \& Schmidt-Nielsen, 1977; Horowitz \& Borut, 1970; Shkolnik \& Borut, 1969). They have several mechanisms for retaining water. For example, typical mammals living in nonarid areas obligate $30 \%-40 \%$ of total water turnover to evaporative water loss, whereas in Acomys the figure is closer to 14\% (Daily \& Haines, 1981). Acomys is also able to rapidly regulate its physiology in the face of dehydration. Urine formation may be reduced by $75 \%$ with $24 \mathrm{~h}$ of water deprivation; with extended deprivation, production can drop by more than 90\%. Vascular permeability can be minimized through tight junctions, allowing water retention during dehydration (Borut et al., 1972). Species differences have also been reported within the Acomys genus. For example, $A$. russatus is better able than $A$. cahirinus to regulate its body temperature in response to heat stress, and is also better able to use salty solutions (Shkolnik \& Borut, 1969). Acomys is reported to be in the middle of the expected range for small desert mammals, with other species whose diets are restricted mostly to seeds exhibiting even more extreme physiological regulation (Daily \& Haines, 1981). Resting oxygen consumption is low, approximately $0.64 \mathrm{ml}$ $\mathrm{O}_{2} / \mathrm{g} / \mathrm{h}$, as compared with $1.27 \mathrm{ml}$ in Mus musculus (Wise, 1977).

\section{Reproduction}

The male reproductive tract has been examined, with sperm first noted at Postnatal Days 35-45 (P35-45). Coagulation studies with seminal vesicle and coagulating gland extracts from laboratory rats, mice, hamsters, gerbils, and guinea pigs have indicated that substrates derived from Acomys are readily coagulated by the extracts from other species, whereas extract from Acomys coagulating glands is less effective when combined with substrates from the other species (Pietz, Foreman, \& Schmitt, 1979).

A light microscopic study of the histology of the ovaries has been reported (Pietz, 1981), as well as an electron microscopic analysis of the cytology of the oocyte (Kang \& Anderson, 1975). Both studies reported that Acomys is quite similar to most murine species. Estrous cycles 
average 11 days (although considerable variability existed), and vaginal smears lack the clear-cut stages seen in rats (Pietz, 1981). The average age of vaginal opening is P45, when evidence of ovulation has also been observed. Acomys has an active luteal phase (Pietz, 1981). In the wild, Acomys preferentially breed after the start of rains, so that young are born during relatively lush seasons (Bodenheimer, 1949; Delany \& Happold, 1979; Neal, 1983; Young, 1976). However, in the laboratory, females cycle year round. A postpartum estrous occurs (Dieterlen, 1961, 1962; Pietz, 1981), which is useful in determining times of conception (Brunjes, 1989). Although there has been informal speculation that the species might form pair bonds, our observations have suggested that this possibility is unlikely. Breeding pairs of Acomys left together can produce litters of pups consistently for several years.

\section{Rhythmicity}

A. cahirinus is a nocturnal species with quite regular circadian cycles. Weaver and Reppert (1987) have reported that robust rhythms in locomotor activity emerge as early as P5. Furthermore, these cycles are entrained by the mother before birth: cross fostering to mothers $180^{\circ}$ out of phase at birth had no effect on subsequent cycles. Also indicative of prenatal entrainment is a correlation between maternal circadian cycles and patterns of 2-deoxyglucose uptake in the fetal suprachiasmatic nucleus. A. russatus has been reported to be active during the daytime (Shkolnik \& Borut, 1969).

\section{Genetics}

As mentioned, the genetics of the genus Acomys is complex, especially in light of the uncertainty over the number of species and races. Zahavi and Wahrman (1956; Wahrman \& Zahavi, 1953) reported that $A$. cahirinus has a diploid genome consisting of $\mathbf{3 8}$ chromosomes, whereas $A$. russatus has 66 . However, the total amount of chromatin is quite similar in the two species (see also Matthey, 1963; Matthey \& Baccar, 1967). A careful examination of the genome of Acomys from Israel (A. cahirinus dimidiatus) and Cyprus (A. nesiotes) indicated that although the number of chromosomes is the same, their morphology is quite different. Although $A$. cahirinus and the Cretan spiny mouse ( $A$. minous) interbreed, their offspring are sterile, suggesting they too may be separate species (Eisenstraut \& Dieterlen, 1969).

\section{DEVELOPMENT}

\section{Prenatal}

Perhaps the most intriguing aspect of the genus Acomys is their precocial birth. Their precocity is undoubtedly an adaptation to the hostile, arid environments in which they are found, allowing pups to attain early independence and perhaps helping them to escape predation. However, such a strategy is not the only successful one used in such environments. Gerbils, for example, fill a very similar niche but are actually born slightly less mature than even the laboratory rat or mouse.

A tacit assumption in biological thinking has been that precocial and altricial species develop similarly, with the simple difference being the time of birth in the two species (Brunjes, 1988). The assumption is understandable; indeed, a superficial examination of Acomys and the rat would lead to the same conclusion. A newborn Acomys and a rat pup of the same postconception age (a P16-17 pup) exhibit striking similarities. Both have open ears and eyes, and both are motorically competent and fully furred. However, more detailed examinations, such as those outlined below, have demonstrated that the pups achieved this state by quite different routes.

Figure 2 depicts morphological development and growth curves in prenatal Acomys. Dieterlen (1963) was the first to publish an examination of prenatal changes in Acomys. In this thoughtful paper, Dieterlen compared external morphological development in the Sinai (A. cahirinus dimidiatus, 19 stages examined spanning E14-37) and Cretan (A. minous, three stages examined: E14, E22-25, and E31) spiny mice with the laboratory rat. Detailed descriptions of changes in body appearance (e.g., eyes, ears, olfactory organs, branchial arches, limb development) are presented, as well as lengths and numbers of somites. $A$. minous was reported to be born a bit less mature (and approximately 2 days earlier) than $A$. cahiri$n u s$, and to develop slightly more rapidly in utero.

Dieterlen (1963) reported that $A$. cahirinus develops much more slowly than the laboratory rat. At the earliest ages examined (approximately E14), Acomys is approximately 2 days less mature than the rat. By the time of birth in the rat (E22), Acomys is more than 5 days less mature. Four days later, the two species exhibit their greatest divergence, with Acomys being more than 7.5 days less mature than the rat.

A series of fascinating papers have been published by a Dutch group comparing the development of function in endodermally derived organs between Acomys and the laboratory rat (Lamers, Mooren, deGraaf, Markiewicz, \& Charles, 1985; Lamers et al., 1982; Oosterhuis, Mooren, Charles, \& Lamers, 1984). The comparisons were made in order to examine perinatal control of enzymatic activity, to determine, for example, whether developmental increases in enzymatic function may be coupled with specific developmental stages or events such as birth. One study (Oosterhuis et al., 1984) examined the development of two enzymes (phosphatidic acid phosphohydrolase and choline-phosphate cytidylyltransferase) involved in the production of the lung surfactant phosphatidylcholine, which is central to pulmonary growth and differentiation. Although the shape of the developmental curves observed for the former enzyme were quite similar in the two species, the increase in Acomys occurred 16 days later. In the rat, two peaks of activity were found in cholinephosphate cytidylyltranserfase activity: one near the time of birth, presumably to ready the lung for postnatal life, and one approximately 2 weeks later in anticipation of 

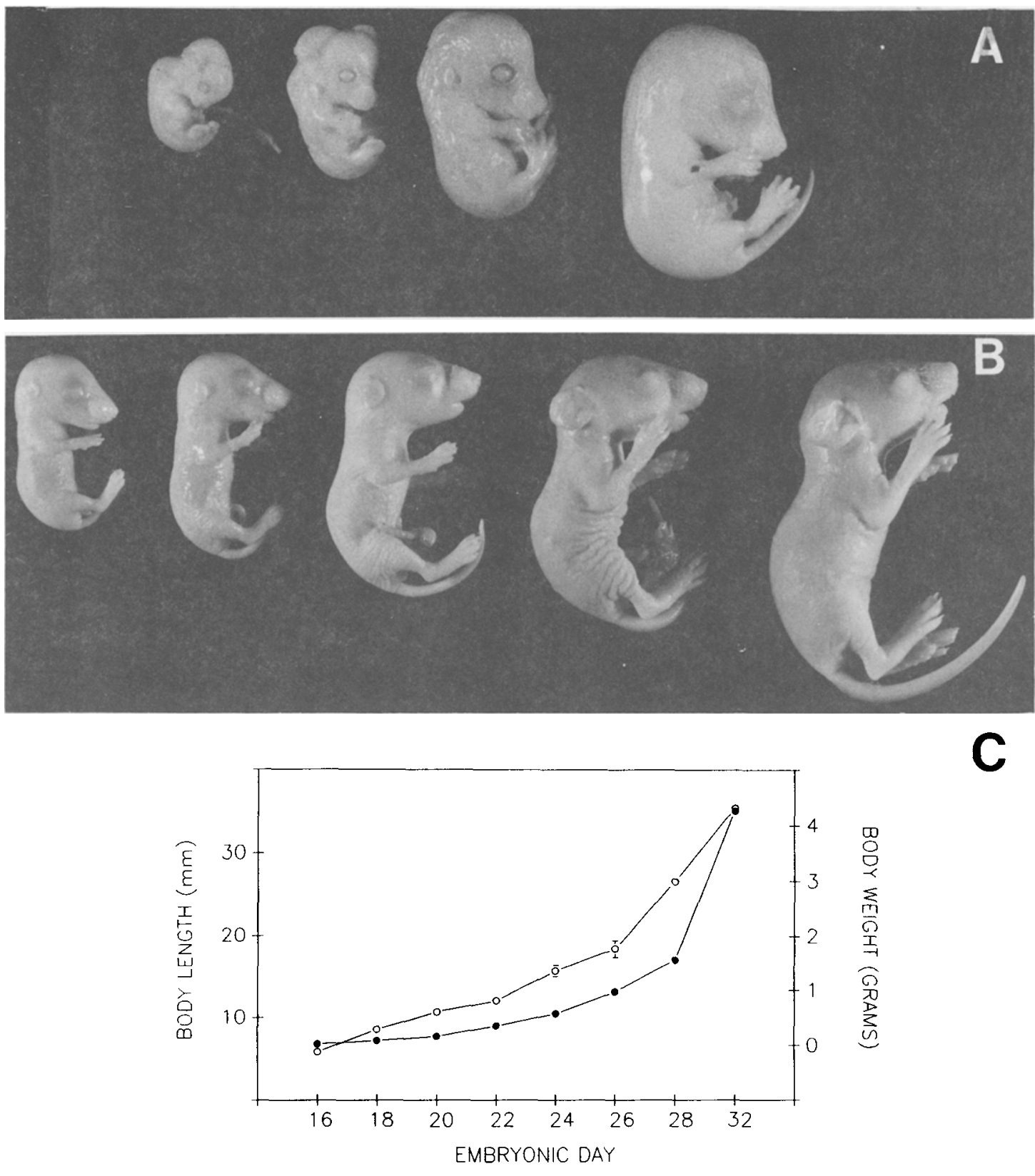

Figure 2. (A) and (B) Bouins-fixed Acomys cahirinus fetuses. (A) Left to right: Embryonic Days 16,18 (with deformed cranium), 20, and 22. (B) Left to right: Embryonic Days 24, 26, 28, 30, and 34. Scale bar is in millimeters. (C) Developmental changes in crown-rump length (open circles) and body weight (filled circles). Bars = 1 SEM.

weaning. Only one peak was seen in Acomys, which occurred near the time of birth. Viewed in terms of time postconception, therefore, quite different patterns were seen in the two species. However, both species exhibited peaks in activity near the time of birth, suggesting a similar sort of developmental regulation.

Studies of urea cycle enzymes from the liver have revealed still different patterns. In the rat, carbamolyphosphate synthetase, arginase, and ornithine trans- carbamoylase activity increases just before birth, remains elevated for the first 5 postnatal days, and then exhibits a slow increase to adult levels. In Acomys, a quite different pattern has been noted, with steady increases occurring throughout the pre- and postnatal periods (Lamers et al., 1985). The results have been interpreted to indicate that the delayed birth in Acomys results in a merging of perinatal and weanling peaks in enzyme activities in the species (Lamers et al., 1985). The fact that the emer- 
gence of the enzymes occurs with a different timetable both within and between species suggests that they are independently regulated.

Lamers et al. (1985) reported that the timetable of prenatal development of choline acetyltransferase activity in the central nervous system is almost identical in Acomys and the rat (however, see below). Two other studies have examined prenatal brain development, and found substantial differences between the species. The first was an examination of Nissl-stained tissue from the developing visual cortex, hippocampus, and olfactory bulb (Brunjes, 1989). Rat and spiny mouse fetuses were collected approximately every other day throughout gestation, beginning at E14 and ending at E34 (approximately 5 days before birth in Acomys, and P12 in the rat). Large differences in the rate of development were observed, substantiating the results of Dieterlen (1963). By E14, Acomys is almost 2 days less mature than the same postconceptionaged rat. For example, the E14 Acomys telencephalic region is simply a pseudostratified neuroepithelium with few postmitotic neurons, and the optic vesicle is still broadly continuous with the lumen of the neural tube, characteristics seen 2 days earlier in the rat. Differences between the species continue to increase: by birth in the rat, Acomys was found to be approximately 4 days less mature (see Figure 3). The largest differences between the species were observed at E28, when Acomys was found to strongly resemble the newborn (E22) rat (e.g., the olfactory ventricle is closed throughout most of the olfactory bulb, the dentate gyrus has formed its characteristic V shape, and the cortical plate is confined to the superficial cortical laminae). By the time of birth in Acomys, the brains of the two species appear grossly similar, although considerable differences in subsequent development have also been reported (see below). In comparison to the rat, therefore, Acomys exhibits considerably slower growth during midgestation, allowing more resolution into early brain development.

A second study examined the generation of the major cell classes in the telencephalon with tritiated thymidine techniques (Brunjes, Korol, \& Stern, 1989). Although in general, cell production begins later and lasts longer in Acomys than in the rat, no simple relationship was found between times of proliferation of the major cell classes in the two species. This finding suggests that there must be regional controls that can be modified both between species (e.g., the general late beginning of cell production seen in Acomys) and within areas. A similar sort of heterochrony has been observed in postnatal brain development, described below.

Little is known about prenatal behavioral development in Acomys. Dieterlen $(1962,1963)$ reported that most newborns he examined exhibited twisted umbilical cords, leading him to the conclusion that considerable movement does take place. Movements resembling respiration were first observed after E26, whereas limb movements were not observed until E32.
Birth occurs approximately 39 days after conception. In a beautiful paper describing the birthing process, Dieterlen (1962) indicated that Acomys exhibit a form of "midwifery." Indeed, female and male Acomys have been observed to actively engage themselves in helping to coax young out of the birth canal, fighting over afterbirths, and so forth. However, Young (1976) housed Acomys females in group and single situations and found that infant mortality was similar between groups, suggesting that this behavior has little effect on the probability of viable births.

\section{Postnatal}

Newborn Acomys pups are covered with a soft gray fur, and their eyes open within several hours after birth. After weaning, a second growth of stiffer brown fur emerges over the lower back area, and later covers most of the dorsum (Strasser, 1968). Growth curves for this period are depicted in Figure 4.

Neural growth. Several studies have examined facets of central nervous system development. In general, these studies have demonstrated that postnatal growth is also different between Acomys and the laboratory rat and mouse. For example, Acomys exhibits more rapid volumetric growth in the hippocampal formation (Brunjes, 1984) and olfactory bulb (Brunjes, 1983) and development of myelin staining (Tessitore \& Brunjes, 1988) than would be expected when compared with same postconceptionaged rats and mice. However, not all regions exhibit this effect. Developmental changes in the density of cells in the visual neocortex, for example, are quite similar between Acomys and Mus (Brunjes, 1985).

In addition to differences between species, interesting variations have also been found within Acomys. Different rates of growth (volumetric expansion) have been noted in several structures. For example, at birth, the olfactory bulb is approximately $50 \%$ of the size attained by P60, and growth is rapid, with the structure achieving $90 \%$ of its adult volume in the first 10 postnatal days. The hippocampal formation is also $50 \%$ of its adult size at birth, but exhibits more gradual development, achieving only $70 \%$ of its adult size by P20. The cerebral cortex is much larger at birth (70\% of its adult size) and exhibits rapid growth during the first 10 postnatal days. The differential growth seen both within and between species suggests that there must be independent control of maturation in the various areas. Differential controls of development such as these might be just the kind of factors that are altered during the divergence of a species from a stem stock. Thus, comparative studies such as these may be a key to understanding the process of evolution (Brunjes, 1985).

It appears that the brain of Acomys is also quantitatively different from that of the rat. For example, D'Udine and Gozzo (1983) have indicated that the hippocampus is larger in Acomys than in the rat. The relative size of the olfactory bulb granule cell zone appears to be smaller in Acomys than in the rat (Brunjes, 1989). 

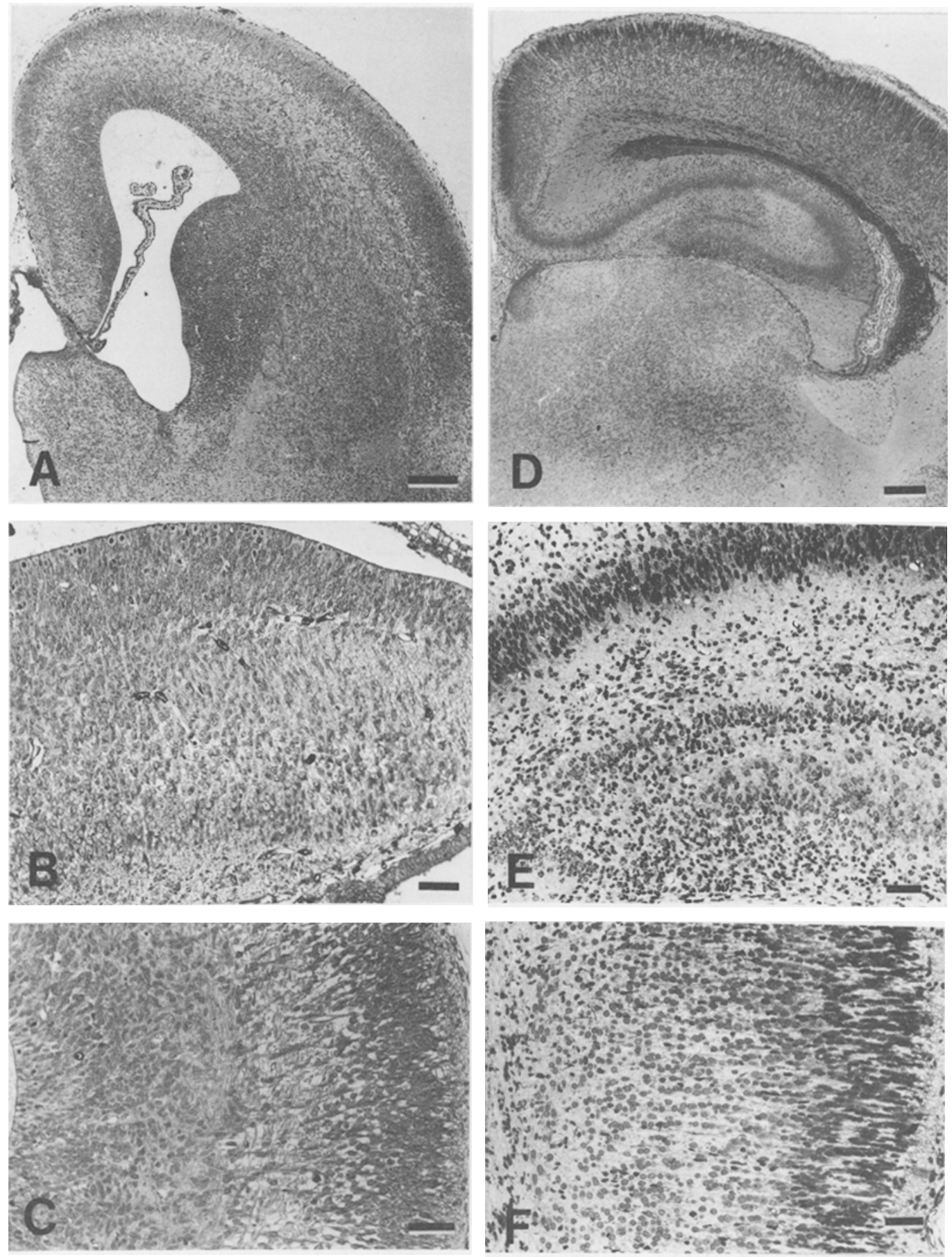

Figure 3. Photomicrographs taken from an Embryonic Day 22 Acomys embryo (left panels) and a same postconception-aged (newborn) rat. (A) and (D). Transerve sections through caudal telencephalon. Scale bars $=0.25 \mathrm{~mm}$. (B) and (E). Higher magnification view of the developing hippocampal region. In the rat $(\mathbf{E})$, the dentate gyrus has formed as a cloud of cells capping the developing pyramidal cell zone. (C) and (F). Higher magnification pictures of developing dorsal (visual) cortex. The cortical plate has almost disappeared in the rat, whereas only a few cells can be seen at the ventral margin in the Acomys. Scale bars for Panels $B, C, E$, and $F=0.05 \mathrm{~mm}$. 


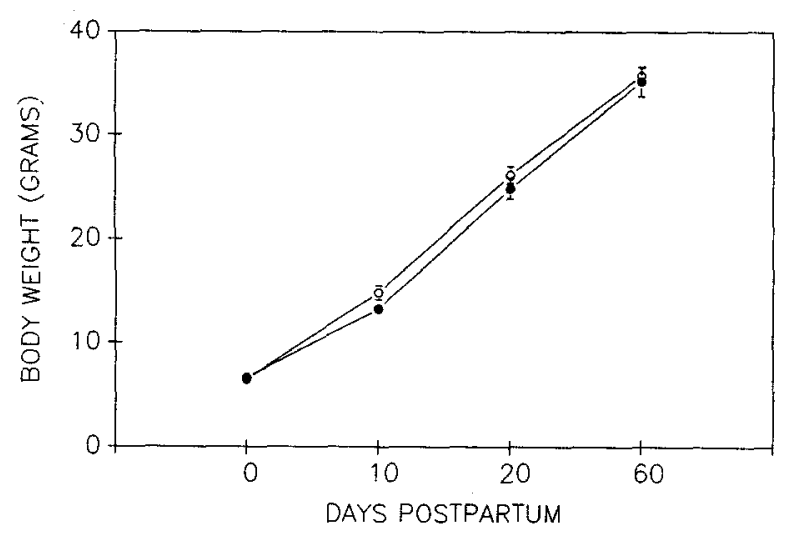

Figure 4. Age-related changes in postnatal body weight for male (open circles) and female (closed circles) Acomys cahirinus. Bars = 1 SEM.

Postnatal development of the cholinergic system (choline acetyltransferase and acetylcholinesterase activity, muscarinic receptor binding sites) has also been reported to differ between Acomys and the rat. As expected due to their longer gestation, Acomys has much higher levels of cholinergic function at birth and a less steep postnatal developmental curve than the rat (Pintor, Alleva, \& Michalek, 1986).

Olfactory bulb maturation has received substantial attention in Acomys (Brunjes, 1983, 1988; Leon, Coopersmith, Ulibarri, Porter, \& Powers, 1984). The rat and mouse bulb have been demonstrated to exhibit considerable postnatal neural plasticity (Brunjes \& Frazier, 1986). For example, closure of a single external naris at birth, thereby blocking airflow on one side of the nasal cavity and depriving receptors of normal stimulation, resulted in a $25 \%$ decrease in the size of the ipsilateral olfactory bulb by P30 (Brunjes \& Frazier, 1986). Brunjes (1988) found that Acomys deprived in a similar way exhibited more dramatic changes than those seen in the altricial animals: the "deprived" olfactory bulbs were $40 \%$ smaller than normal bulbs. Furthermore, in the rat, there is a "sensitive period" for the effects of such deprivation: naris closure after P10, followed by a survival period of 30 days, has relatively little effect on bulb size. However, unilateral deprivation in Acomys as late as P30 still resulted in a greater than $20 \%$ reduction in the size of the olfactory bulb. Therefore, Acomys actually appears to be more affected by alterations in levels of environmental stimulation than does the rat or mouse, and as such is an excellent species for examinations of neural plasticity.

Behavioral. A large number of studies examining early behavioral development in $A$. cahirinus have been reported, primarily by $\mathrm{R}$. H. Porter and his colleagues (Porter, 1986, 1987, 1989). Although these studies are of a diverse nature and overlap both technically and conceptually, they have been broken down into three categories (see also the section on parental behavior).

1. Early odor preferences. Some of the first behavioral studies reported in Acomys examined "olfactory imprint- ing." Acomys pups were given $1 \mathrm{~h}$ of exposure to either cumin or cinnamon on the day of birth. Twenty-four hours later, they were given a two-choice preference test and were found to prefer the odor to which they had been previously exposed (Porter \& Etscorn, 1974). Like avian imprinting, the odor preferences exhibited somewhat of a primacy effect: the first odor experienced was preferred over a second as long as exposure times were kept equal (Porter \& Etscorn, 1975). Furthermore, a sensitive period appeared to exist, with odor exposure on P1-3 being most effective in inducing preferences (Porter \& Etscorn, 1976). Janus $(1988,1989)$ has recently extended these findings by using naturally occurring odors, more complex testing situations, and longitudinal designs. As a result, the phenomena look less like classical imprinting; for example, reliable preferences could be demonstrated with exposure as late as P16.

2. Maternal pheromones. A long series of studies performed by Leon and his collaborators (e.g., Leon, 1974; Leon \& Behse, 1977) examined the attraction of young rat pups to a diet-specific odor of dams. Preferences of a similar sort have been demonstrated in Acomys. Acomys pups were given a series of two-choice preference tests for bedding from a number of different sources. Lactating females produce an attractant that is emitted for at least 35-38 days if lactation is maintained (Porter \& Doane, 1976; Porter, Doane, \& Cavallaro, 1978). The preference appears to be experience-dependent: Acomys pups prefer bedding from lactating females eating a diet similar to the maternal one over that from mothers eating novel food (Doane \& Porter, 1978; Porter \& Doane, 1976). Acomys pups will also be attracted to bedding from lactating Acomys females over lactating Mus females, although early cross-fostering reverses these preferences (Porter, Deni, \& Doane, 1977). Given the choice between bedding from a lactating Acomys female on a diet different from the maternal one, and bedding from a lactating Mus female on a diet similar to that in the home nest, Acomys pups chose on the basis of diet rather than species. Therefore, dietary cues appear to be more salient, although pups can discriminate on the basis of species cues as well (Porter \& Doane, 1977). Preferences for bedding from lactating females appear to wane around P25, when pups begin to prefer bedding from nonlactating females (Porter, Doane, \& Cavallaro, 1978).

3. Development of social preferences. Like rats (see Alberts, 1981), young Acomys pups huddle vigorously. Newborns spend large amounts of time in contact with each other and their parents (Deni, Wilson, \& Reisert, 1983). An age-related decrease in the time spent engaged in this important behavior is apparent. For example, from P14 to P22, the mean time spent in contact with siblings decreased from $43 \%$ to $4.4 \%$ of an observational period. Once again, experience seems to direct the behavior: pups raised with littermates spend more time huddling than do pups reared alone (Porter, Cernoch, \& Matochik, 1983; Porter, Tepper, Baumeister, Cernoch, \& Matochik, 1982). Preferences for associating with siblings emerge as early as P14-16 (Porter \& Wyrick, 1979). 
Considerable attention has been given to examining social preferences of weanling (P25-30) Acomys. Pups at this age preferentially huddle with littermates (Porter, Wyrick, \& Pankey, 1978). Experience seems to be important in regulating the preferences. Previous exposure to strange weanlings increases their attractiveness, whereas individual isolation for 8 days diminishes preferences for siblings (Porter \& Wyrick, 1979; Porter, Wyrick, \& Pankey, 1978). Pups cross-fostered between Acomys mothers at $\mathrm{P} 10$ or $\mathrm{P} 20$ prefer to associate with foster pups rather than with siblings. The effect is at least partially due to the effects of maternal cues. For example, siblings separated but suckled by the same mother prefer to associate, whereas siblings nursed by separate dams do not (Porter, Tepper, \& White, 1981; see also Porter, Matochik, \& Makin, 1984), which suggests that olfactory cues may be significant. Indeed, pups made anosmic with zinc sulfate infusions have reduced preferences for siblings, and odorizing pups can decrease their preferences for siblings and increase the attractiveness of strangers (Porter, Matochik, \& Makin, 1983; Porter, McFadyen-Ketchum, \& King, 1989). Acomys pups can discriminate between littermates and nonlittermates when the diet of both groups are held constant. This preference disappears when pups are rendered anosmic (Porter, 1988).

Other studies. Ingestive behavior has also been examined in young Acomys. Solid food consumption occurs initially about P4-6 (Dieterlen, 1963; D'Udine, Gerosa, \& Drewett, 1980; Porter, Cavallaro, \& Moore, 1980). Estimates of when weaning occurs in Acomys vary widely. Young (1976), for example, claims that pups usually are weaned by P28 but can successfully be weaned as early as P18. Pups born more or less than 1 standard deviation away from mean body weight tend to retain their standing throughout the first 4 weeks of life. Both the maternal environment and the ability of pups to orient to lactating females may play a a role in the maintenance of these differences (Porter, Makin, \& Matochik, 1986).

\section{OTHER STUDIES OF ACOMYS}

A number of other topics have been examined in Acomys in varying detail. Several of these are mentioned below.

Aggressive behavior. Adult female Acomys are more aggressive than males (Andres \& Deni, 1982; Moore, McRainey, \& Hicks, 1981; Porter, 1976). Porter (1976) has offered a lengthy description of aggressive behavior observed between triads of all combinations of sexes. He reported that chasing, not fighting, appears to be the primary aggressive behavior, that there are apparently few appeasement gestures, and that environmental stimuli (e.g., home vs. strange cages) affect levels of aggression. Moore et al. (1981) reported that REM sleep deprivation resulted in temporary elevations in aggression in females. Females are more likely to treat sexually inexperienced males as intruders than males with previous breeding experience (Andres \& Deni, 1982)
Diabetes. A number of studies have examined strains of $A$. cahirinus which exhibit obesity, glycosuria, and hypertrophy of the islets of Langerhans. In most adult animals, approximately $1 \%$ of the endocrine pancreas is occupied by islets. Gonet, Stauffacher, Pictet, and Renold (1965; see also Pictet, Orci, Gonet, Rouiller, \& Renold, 1967) calculated that in diabetic Acomys, the ratio is closer to $15 \%$, although the insulin content of the islets does not differ (Nesher, Abramovitch, \& Cerasi, 1985). Insulin release is defective when the mice are confronted with a number of challenges (Cameron, Stauffacher, Orci, Amherdt, \& Renold, 1972; Gutzeit et al., 1974; Nesher et al., 1985; Rabinovitch, Gutzeit, Grill, Kikuchi, Renold, \& Cerasi, 1975; Rabinovitch, Gutzeit, Kikuchi, Cerasi, \& Renold, 1975; Rabinovitch, Gutzeit, Renold, \& Cerasi, 1975). Acomys does not exhibit a rapid peak in insulin secretion to a glucose challenge, and pancreatic responsiveness is quite delayed, perhaps due to deficits in B-cell adenylate cyclase/cyclic AMP responses (Rabinovitch, Gutzeit, Kikuchi, Cerasi, \& Renold, 1975). Morphological studies have failed to find the innervation seen in the normal pancreas. Electrical stimulation of the vagus does result in increased plasma insulin levels in Acomys, but the response is not blocked by several cholinergic muscarinic antagonists, including atropine methylnitrate and carbachol (Ionescu \& Jeanrenaud, 1988). However, liver glucose production may be more sensitive to insulin in Acomys than in other rodents, limiting the consequences of decreased insulin output (Cerasi \& Jeanrenaud, 1979). Evidence exists that the diabetes seen in Acomys may be a result of obesity due to diets containing high percentages of fats coupled with a normally low insulin response (Gutzeit, Renold, Cerasi, \& Shafrir, 1979). As a result, the species has been suggested as a good animal model for chemical or latent diabetes (Gutzeit et al., 1979; Nesher et al., 1985).

Studies of metabolic activity prompted by the work with diabetes have indicated that compared with laboratory rodents, Acomys has (1) a relatively small liver $3.6 \%$ of body weight, compared to $6.1 \%$ in albino mice and $4.2 \%$ in rats); (2) lower activity of several enzymes of glycolytic pathways, including glucokinase, pyruvate kinase, aldolase, glucose-6-phosphate dehydrogenase, and 6phosphogluconate dehydrogenase; (3) increased activity in several enzymes involved in gluconeogenesis (e.g., glucose-6-phosphatase, pyruvate carboxylase); (4) relaively similar levels of enzymes involved in amino acid metabolism (e.g., aminotransferases); and (5) differential liver responsiveness to starvation, including a different threshold of diet carbohydrate, which triggers changes in liver enzyme activity (Gutman, Hasin, \& Shafrir, 1972).

Exploratory behavior. Birke, D'Udine, and Albonetti (1981) demonstrated that Acomys and the laboratory mouse exhibit quite different behaviors when placed in a strange environment. Adults were placed in a small box that opened into an adjacent arena. Mice exhibited quite cautious behavior, making only short forays into the open field. Acomys, however, moved quickly into the area and made rapid dashes around the perimeter. Acomys also 
spent more time investigating objects placed in the open field. For example, a large piece of pipe was explored by Acomys, but was used as a refuge by Mus. When frightened, Mus tended to use the pipe as a haven, whereas Acomys simply fled. Male Acomys appear to be more cautious than females (Birke \& Sadler, 1986a).

Species differences in distractibility have also been examined (Birke \& Sadler, 1986b). Male and female Acomys and Mus were trained to exhibit stable performance in a runway situation. When novel stimuli were added, the performance of male Acomys was much more affected than that of male Mus. The opposite relationship was encountered for females of the two species.

Feeding. Naloxone attenuates both food and water intake in Acomys (as it does in the rat but not in the hamster), indicating an opioid-sensitive feeding mechanism (Czech, 1987). Feeding in Acomys is not stimulated by 2-deoxyglucose, although it does cause hyperglycemia. Insulin injections will induce moderate feeding bouts (Czech, 1988). Food sharing has also been examined in young Acomys (Porter, Moore, \& White, 1981).

Learning. Although it has been reported that desert species have difficulties learning illness-induced fluid aversions, this does not seem to be the case for Acomys (Etscorn, 1977). Deni (1977) has reported that Acomys has a difficult time inhibiting a previously learned response.

Parental behavior. With the large body of literature examining early behavioral development in Acomys, one would expect a substantial interest in the role of the parents. Indeed, beginning with Dieterlen's (1962) fascinating early account of midwifing (see above), there has been quite a bit of interest in the respective roles of both parents (D'Udine et al., 1980; Makin \& Porter, 1984; Porter et al., 1980; Porter \& Doane, 1978; Szijarto et al., 1985). Acomys, as mentioned, tend to live in colonies without nests. Newly parturient mother will nurse any pup. By P8, mothers prefer to nurse their own offspring, but will still suckle others. Dominant mothers may claim all pups and exclude other mothers (Porter \& Doane, 1978; Porter et al., 1980). Time spent nursing declines throughout the first 4 postnatal weeks, with little apparent after P26-30 (Porter et al., 1980). Female spiny mice assume a nursing posture similar to that seen in rats, and a typical stretch reflex is observed in pups with milk letdowns (D'Udine et al., 1980). In a similar fashion, newly parturient females will retrieve any pup, but with age begin to retrieve their own pups first (Porter \& Doane, 1978). Retrieval rates decrease as pups age, as a result of both changes in the stimulus characteristics of the pup and the state of the mother (Porter et al., 1980).

Although pups spend time huddling with both parents (indeed, they may spend much more time with the father than the mother; Makin \& Porter, 1984; Szijarto et al., 1985), a considerable amount of time is spent with all family members huddling together. However, in a two-choice situation, fathers will spend more time in contact with unfamiliar pups than with their own, with the age of the unfamiliar pups apparently making little difference. Ex- perienced fathers appear to treat pups differently than do those with no previous pup contact (Makin \& Porter, 1984).

Sensory capabilities. Langley (1988) examined the role of audition, vision, and olfaction in prey (cricket) catching in Acomys. Olfaction and audition appeared to be the most important modalities, but, reinforcing their classification as a nonspecialized omnivore, they could easily shift dominant modalities when needed. Greenberg (1986) reported that Acomys has good depth perception and that they rely more heavily on visual cues than do gerbil species. Several studies examining social behavior in Acomys have indicated that the olfactory system plays a dominant role in the species (see the section on prenatal behavior; Matochik, 1988; Porter \& Doane, 1979; Porter, Matochik, \& Makin, 1986; Porter \& Ruttle, 1975; Porter, Sentell, \& Makin, 1987; Porter \& Treadway, 1974).

Taste preferences. Harriman (1980) investigated taste preferences of adult Acomys in a series of two-choice drinking tests. Sugars (fructose, glucose, lactose, maltose, and sucrose) were approached, whereas salts $\left(\mathrm{MgSO}_{4}\right.$, $\mathrm{KCL}, \mathrm{NaCl})$ and acids $(\mathrm{HCl}$ and citric) were treated indifferently or avoided. Acomys rejected or treated hypotonic $\mathrm{NaCl}$ solutions indifferently.

\section{CONCLUSIONS}

Why are Acomys precocial? This question has been grappled with before (Dieterlen, 1963), with few apparent answers. Dieterlen (1963) and Gould (1977) have argued that precocity is a derived state. Evolutionary theory would suggest that the move toward precocial offspring occurs in order to aid survival-that demands made by particular niches are most easily met by producing young that are relatively mature. The most obvious quality of Acomys' niche is its harshness, which suggests that this might be the factor that favors the production of competent young. But, as mentioned previously, precocial young are not necessary to survive in an arid niche; quite altricial animals, such as gerbils, flourish in similar environments.

Dieterlen (1963), reviewing a large body of literature, found three rodent species with unusually long gestations: Acomys, Sigmadon, and Nyctomys. All live in widely different habitats, have large variations in social organization, and are subjected to varying degrees of predation. Although that study indicates that precocial young have independently evolved several times, it leaves explanations of the factors directing evolution towards precocial young difficult to formulate. Dieterlen's study also emphasized the fact that rodent species have been quite successful in populating almost every area through the use of a multitude of strategies.

Nevertheless, the present review indicates that large differences in brain growth, physiology, and behavior exist between the laboratory rat and mouse and Acomys. As a result, they afford uniquely suitable species for interspecific comparisons, perhaps allowing insight into the 
mechanisms that regulate development (Gould, 1977; Bonner, 1982; Raff \& Kaufmann, 1983), and thus greater understanding of both ontogeny and phylogeny.

\section{REFERENCES}

ALberTs, J. R. (1981). Ontogeny of olfaction: Reciprocal roles of sensation and behavior in the development of perception. In R. N. Aslin, J. R. Albert, \& M. R. Petersen (Eds.), Development of perception, psychobiological perspectives (Vol. 1, pp. 322-357). New York: Academic Press.

ANDRES, S. L., \& DENI, R. (1982). Social and individual behavior of female spiny mice (Acomys cahirinus) paired with sexually experienced and inexperienced males. Bulletin of the Psychonomic Society, 19, 311-314.

Birke, L. I., D'Udine, B., \& Albonetti, M. E. (1981). Exploratory behavior of two species of murid rodents, Acomys cahirinus and Mus musculus: A comparative study. Behavioral \& Neural Biology, 43, 143-161.

Birke, L. I. A., \& SAdLer, D. (1986a). Patterns of exploratory behavior in the spiny mouse Acomys cahirinus. Behavioral \& Neural Biology, 45, 88-106.

Birke, L. I. A., \& Sadler, D. (1986b). Species and sex differences in response to a novel stimulus in Acomys cahirinus and Mus musculus. Perceptual \& Motor Skills, 63, 1131-1136.

BODENhermer, F. S. (1949). Ecological and physiological studies on some rodents. Physiologia Comparata et Oecologia, 1, 376-389.

Bonhomme, F., Iskandar, D., Thaler, L., \& PetTer, F. (1985). Electromorphs and phylogeny in muroid rodents. In W. P. Luckett \& J. L. Hartenberger (Eds.), Evolutionary relationships among rodents: A multidisciplinary analysis (pp. 643-670). New York: Plenum.

BONNER, J. T. (1982). Evolution and development. Berlin: SpringerVerlag.

Borut, A., Horowitz, H., \& CASTEl, M. (1972). Blood volume regulation in the spiny mouse: Capillary permeability changes due to dehydration. Symposia of the Zoological Society of London, 31, 175-189.

BRUNJes, P. C. (1983). Olfactory bulb maturation in Acomys cahirinus: Is neural growth similar in precocial and altricial murids? Developmental Brain Research, 8, 335-341.

BRUNJES, P. C. (1984). Hippocampal maturation in the precocial murid rodent Acomys cahirinus, Brain, Behavior \& Evolution, 24, 58-74.

BRUNJES, P. C. (1985). A stereological study of neocortical maturation in the precocial mouse Acomys cahirinus. Developmental Brain Research, 19, 279-287.

Brunjes, P. C. (1988). Plasticity and precocity: Odor deprivation and brain development in the precocial mouse Acomys cahirinus. Neuroscience, 24, 579-582.

BruNJES, P. C. (1989). A comparative study of prenatal development in the olfactory bulb, neocortex and hippocampal region of the precocial mouse Acomys cahirinus and the rat. Developmental Brain Research, 49, 7-25.

Brunjes, P. C., \& Frazier, L. L. (1986). Maturation and plasticity in the olfactory system of vertebrates. Brain Research Reviews, 11, $1-45$.

Brunjes, P. C., Korol, D. L., \& Stern, K. G. (1989). Prenatal neurogenesis in the telencephalon of the precocial mouse Acomys cahirinus. Neuroscience Letters, 107, 114-119.

Cameron, D. P., Stauffacher, W., Orci, L., Amherdt, M., \& ReNold, A. E. (1972). Defective immunoreactive insulin secretion in the Acomys cahirinus. Diabetes, 21, 1060-1071.

Carleton, M. D. (1984). Introduction to rodents. In S. Anderson \& J. K. Jones, Jr. (Eds.), Orders and families of recent mammals of the world (pp. 255-265). New York: Wiley.

Carleton, M. D., \& Musser, G. G. (1984). Muroid rodents. In S. Anderson \& J. K. Jones, Jr. (Eds.), Orders and families of recent mammals of the world (pp. 289-379). New York: Wiley.

Cerasi, E., \& Jeanrenaud, B. (1979). Glucose production by the perfused liver of the spiny mouse (Acomys cahirinus): Sensitivity to glucagon and insulin. Israeli Journal of Medical Science, 15, 134-139.
Corbet, G. B. (1978). The mammals of the Palaearctic region: A taxonomic review. London: British Museum.

Corbet, G. B., \& Hill, J. E. (1986). A world list of mammalian species (2nd ed.). London: British Museum.

CzeCH, D. A. (1987). Opioid modulation of ingestive behaviors in the spiny mouse (Acomys cahirinus). Life Sciences, 41, 935-940.

CzECH, D. A. (1988). Effect of insulin and 2-deoxy-d-glucose on feeding and plasma glucose levels in the spiny mouse. Physiology \& Behavior, 43, 765-769.

DAILY, C. S., \&AINES, H. B. (1981). Evaporative water loss and water turnover in chronically and acutely water-restricted spiny mice (Acomys cahirinus). Comparative Biochemistry \& Physiology, 68A, 349-354.

DELANY, M. J., \& HAPPOLD, D. C. D. (1979). Ecology of African mammals. London: Longman.

DENI, R. (1977). Resistance to extinction of a lever press in spiny mice (Acomys cahirinus). Perceptual \& Motor Skills, 45, 447-450.

DenI, R., Wilson, S., \& REISERT, D. (1983). The approach and proximity behavior of spiny mouse pups (Acomys cahirinus) toward strange neonates: Effects of gender and species of stimulus pup. Bulletin of the Psychonomic Society, 21, 239-242.

DieTerLen, F. (1961). Beitrage zur Biologie der Stachelmaus, Acomys cahirinus dimidiatus Cretzschmar. Zeitschrift für Saugertierkande, 26, 1-13.

Dieterlen, F. (1962). Geburt und Geburtshilfe bei der Stachelmaus Acomys cahirinus. Zeitschrift für Tierpsychologie, 19, 191-222.

DieTERLEN, F. (1963). Vergleichende untersuchungen zur Ontogenese von Stachelmaus (Acomys) und Wanderratte (Rattus norvegicus): Beitrage zum Nesthocker-Nestflüchter-Problem bei Nagetieren. Zeitschrift für Saugetierkünde, 28, 193-227.

Done, H. M., Porter, R. H. (1978). The role of diet in motherinfant reciprocity in the spiny mouse. Developmental Psychobiology, 11, 271-277

D'Udine, B., \& Alleva, E. (1988). The Acomys cahirinus (spiny mouse) as a new model for biological and neurobehavioral studies. Polish Journal of Pharmacology \& Pharmacy, 40, 525-534.

D'Udine, B., Gerosa, E., \& Drewett, R. F. (1980). Maternal behavior and the milk ejection reflex in a precocial muroid (Acomys cahirinus). Behavioral \& Neural Biology, 28, 378-381.

D'Udine, B., \& Gozzo, S. (1983). Archicortex and neocortex in the precocial muroid Acomys cahirinus. A comparison with two altricial species: Mus musculus and Ratmus norvegicus. International Journal of Neuroscience, 20, 255-264.

EISENBERG, J. F. (1981). The mammalian radiations. Chicago: University of Chicago Press.

Eisenstraut, M., \& DieTERlen, F. (1969). Kreuzüngsversuche mit den Beiden Stachelmaus-arten Acomys dimidiatus Cretzschmar und Acomys minous Bate (Murideae; Rodentia). Zoologische Beitrage, 15, 329-346.

ETsCORN, F. (1977). Illness-induced aversion learning in a desert species of rodent (Acomys cahirinus). Physiological Psychology, 5, 336-338.

FlynN, L. J., Jacobs, L. L., Lindsay, E. H. (1985). Problems in muroid phylogeny: Relationships to other rodents and origin of major groups, and phylogeny in muroid rodents. In W. P. Luckett \& J. L. Hartenberger (Eds.), Evolutionary relationships among rodents: Multidisciplinary analysis (pp. 589-616). New York: Plenum.

Gonet, A. E., Stauffacher, W., Pictet, R., \& Renold, A. E. (1965). Obesity and diabetes mellitus with striking congenital hyperplasia of the islets of Langerhans in spiny mice (Acomys cahirinus): I. Histological findings and preliminary metabolic observations. Diabetologia, 1, 162-171.

Gould, S. J. (1977). Ontogeny and phylogeny. Cambridge, MA: Belknap.

GrEenBERG, G. (1986). Depth perception in Mongolian gerbils (Meroines unguiculatus) and spiny mice (Acomys russatus and $A$. cahirinus). Journal of Comparative Psychology, 100, 81-84.

Gutman, A., Hasin, M., \& Shafrir, E. (1972). Adaptive responses in enzyme activities of Israeli spiny mice (Acomys cahirinus). Israeli Journal of Medical Science, 8, 364-381.

Gutzeit, A., Rabinovitch, A., Studer, P. P., Trueheart, P. A., Cerasi, E., \& Renold, A. E. (1974). Decreased intravenous glu- 
cose tolerance and low plasma insulin response in spiny mice (Acomys cahirinus). Diabetologia, 10, 667-670.

Gutzeit, A., Renold, A. E., Cerasi, E., \& Shafrir, E. (1979). Effect of diet-induced obesity on glucose and insulin tolerance of a rodent with a low insulin response (Acomys cahirinus). Diabetes, 28, 777-784.

Haines, H., \& SChmidt-NiELSEN, B. (1977). Kidney function in spiny mice (Acomys cahirinus). Bulletin of the Mt. Desert Island Biological Laboratory, 17, 94-95.

Harriman, A. E. (1980). Preferences by Egyptian spiny mice for solutions of sugars, salts and acids in Richter-type drinking tests. Perceptual \& Motor Skills, 50, 1075-1081.

HARTENBERGER, J. L. (1985). The order rodentia: Major questions on their evolutionary origin, relationships and suprafamilial systematics. In W. P. Luckett \& J. L. Hartenberger (Eds.), Evolutionary relationships among rodents: Multidisciplinary analysis (pp. 1-35). New York: Plenum.

Horowitz, M., \&ORUT, A. (1970). Effect of acute dehydration on body fluid compartments in three rodent species: Rattus norvegicus, Acomys cahirinus and Meriones crassus. Comparative Biochemistry \& Physiology, 35, 283-290.

Ionescu, E., \& Jeanrenaud, B. (1988). Effect of electrical stimulation of the vagus nerve in insulinemia and glycemia in Acomys cahirinus mice. Endocrinology, 123, 885-890.

JACOBS, L. L. (1978). Fossil rodents (Rhizomyidae and Muridae) from Neogene Siwalik deposits, Pakistan. Museum of Northern Arizona Bulletin, Series 52, 1-103.

JANUS, C. (1988). The development of responses to naturally occurring odours in spiny mice Acomys cahirinus. Animal Behavior, 36, $1400-1406$.

JANUS, C. (1989). The development of olfactory preferences for artificial odors briefly experienced by the precocial spiny mouse young. Behavioral \& Neural Biology, 52, 430-436.

KANG, Y.-H., \& ANDERSON, W. A. (1975). Ultrastructure of the oocytes of the Egyptian spiny mouse (Acomys cahirinus). Anatomical Record, 182, 175-200.

KINGDON, J. (1974). East African mammals: An atlas of evolution in Africa (Vol, II, Pt. B): Hares and Rodents. London: Academic Press.

Lamers, W. H., Mooren, P. G., De Graaf, A., Markiewicz, A., \& Charles, R. (1985). Perinatal organ development in rat and spiny mouse: Its relation to altricial and precocial timing of birth. In C. T. Jones \& P. W. Nathanielsz (Eds.), The physiological development of the fetus and newborn (pp. 41-45). London: Academic Press.

lamers, W. H., Mooren, P. G., Oosterhuis, W., Lunstroo, H., DE GraAF, A., \& Charles, R. (1982). The relation between the developmental timing of birth and developmental increases in urea cycle enzymes. Advances in Experimental Medicine \& Biology, 153, 229-240.

LANGLEY, W. M. (1988). Spiny mouse's (Acomys cahirinus) use of its direction senses in prey localization. Behavioral Processes, 16, 67-73.

Lavocat, R., \& Parent, J. P. (1985). Phylogenetic analysis of middle ear features in fossil and living rodents. In W. P. Luckett \& J. L. Hartenberger (Eds.), Evolutionary relationships among rodents: Multidisciplinary analysis (pp. 333-354). New York: Plenum.

Leon, M. (1974). Maternal pheromone. Physiology \& Behavior, 13, 441-453.

LEON, M., \& BEHSE, J. H. (1977). Dissolution of the pheromonal bond: Waning of approach response by weanling rats. Physiology \& Behavior, 18, 393-397.

Leon, M., Coopersmth, R., Ulibarri, C., Porter, R. H., \& Powers, J. B. (1984). Development of olfactory bulb organization in precocial and altricial rodents. Developmental Brain Research, 12, 45-53.

MAKIN, J. W., \& PORTER, R. H. (1984). Paternal behavior in the spiny mouse (Acomys cahirinus). Behavioral \& Neural Biology, 41, 135-151.

MATOCHIK, J. A. (1988). Role of the main olfactory system in recognition between individual spiny mice. Physiology \& Behavior, 42, 217-222.

MattheY, R. (1963). Polymorphisme chromosomique intraspecifique et intraindividuel chez Acomys minous bate (Mammalia-rodentiamuridae). Enude cytologique des hybrides Acomys minouse males $\times$
Acomys cahirinus females: Le mehanisme des fusions centriques. Chromosoma, 14, 468-497.

MATtheY, R., \&aCCAR, H. (1967). La formule chromosomique d'Acomys seurati et la cytogenetique d'Acomys palearctiques. Revue Suisse de Zoologie, 74, 546.

MOORE, J. D., MCRAINEY, L., \& HICKS, R. A. (1981). REM sleep deprivation increases dominance behaviors in female spiny mice. Bulletin of the Psychonomic Society, 17, 246-248.

NEAL, B. R. (1983). The breeding patterns of 2 species of spiny mice in central Kenya. Mammalia, 47, 311-321.

Nesher, R., Abramovitch, E., \& Cerasi, E. (1985). Correction of diabetic pattern of insulin release from islets of the spiny mouse (Acomys cahirinus) by glucose priming in vitro. Diabetologica, 28, 233-236.

Oosterhuis, W. P., Mooren, P. G., Charles, R., \& Lamers, W. H. (1984). Perinatal development of the lung in rat and spiny mouse: Its relation to altricial and precocial timing of birth. Biology of the Neonate, 45, 236-243.

PetTer, F. (1954). Remarques biologiques sur des rats epineux du genre Acomys, repartition as Sahara. Mammalia, 18, 390-395.

Petter, F., \& Roche, J. (1981). Remarques preliminaires sur la systematique des Acomys (Rongeurs, Muridae): Peracomys, sous-genre noveau. Mammalia, 45, 381-383.

Pictet, R., Orci, L., Gonet, A. E., Roulller, C., \& Renold, A. E. (1967). Ultrastructural studies of the hyperplastic islets of Langerhans of spiny mice (Acomys cahirinus) before and during the development of hyperglycemia. Diabetologica, 3, 188-211.

PieTZ, B. (1981). The oestrous cycle of the spiny mouse (Acomys cahirinus). Journal of Reproduction \& Fertility, 61, 453-459.

Pietz, B., Foreman, D., \& SCHMITT, M. (1979). The reproducive tract of the male spiny mouse (Acomys cahirinus) and coagulation studies with other species. Joumal of Reproduction \& Fertility, 57, 183-188.

Pintor, A., Alleva, E., \& Michalek, H. (1986). Postnatal maturation of brain cholinergic systems in the precocial murid Acomys cahirinus: Comparison with the altricial rat. International Journal of Developmental Neuroscience, 4, 375-382.

PORTER, R. H. (1976). Sex-differences in the agonistic behavior of spinymice (Acomys cahirinus). Zeitschrift fur Tierpsychologie, 40, 100-108.

PORTER, R. H. (1986). Chemical signals and kin recognition in spiny mice (Acomys cahirinus). In D. Duvall, D. Muller-Schwarze, \& R. M. Silverstein (Eds.), Chemical signals in vertebrates (Vol. 4, pp. 397411). New York: Plenum.

PorTer, R. H. (1987). Kin recognition: Functions and mediating mechanisms. In C. Crawford, M. Smith, \& D. Krebs (Eds.), Sociobiology and psychology: Ideas, issues and applications (pp. 175-203). Hillsdale, NJ: Erlbaum.

PORTER, R. H. (1988). The ontogeny of sibling recognition in rodents: Superfamily Muroidea. Behavioral Genetics, 18, 483-494.

PORTER, R. H. (1989). Littermate influences on behavioral and physiological development in spiny mice. In D. Dewsbury (Ed.), Contemporary issues in comparative psychology (pp. 300-315). Sunderland, MA: Sinauer.

Porter, R. H., Cavallaro, S. A., \& Moore, J. D. (1980). Developmental parameters of mother-offspring interactions in Acomys cahirinus. Zeitschrift für Tierpsychologie, 53, 153-170.

Porter, R. H., Cernoch, J. M., \& Matochix, J. A. (1983). Littermate influences on behavioral development in Acomys cahirinus and Mus musculus. Zeitschrift für Tierpsychologie, 62, 93-104.

Porter, R. H., Deni, R., \& DonNe, H. M. (1977). Responses of Acomys cahirinus pups to chemical cues produced by a foster species. Behavioral Biology, 20, 244-251.

PORTER, R. H., \& DOANE, H. M. (1976). Maternal pheromone in the spiny mouse (Acomys cahirinus). Physiology \& Behavior, 16, 75-78. PorTer, R. H., \& DoANe, H. M. (1977). Dietary-dependent crossspecies similarities in maternal chemical cues. Physiology \& Behavior, 19, 129-131.

PoRTER, R. H., \& DoANe, H. M. (1978). Studies of maternal behavior in spiny mice (Acomys cahirinus). Zeitschrift fitr Tierpsychologie, 47, 225-235.

Porter, R. H., \& DoAne, H. M. (1979). Responses of spiny mouse 
weanlings to conspecific chemical cues. Physiology \& Behavior, 23, 75-78.

Porter, R. H., Doane, H. M., \& Cavallaro, S. A. (1978). Temporal parameters of responsiveness to maternal pheromone in Acomys cahirinus. Physiology \& Behavior, 21, 563-566.

PORTER, R. H., \& ETSCORN, F. (1974). Olfactory imprinting resulting from brief exposure in Acomys cahirinus. Nature, 250, 732-733.

PORTER, R. H., \& ETSCORN, F. (1975). A primacy effect for olfactory imprinting in spiny mice (Acomys cahirinus). Behavioral \& Neural Biology, 15, 511-517.

Porter, R. H., \& ETSCoRN, F. (1976). A sensitive period for the development of olfactory preferences in Acomys cahirinus. Physiology \& Behavior, 17, 127-130.

Porter, R. H., Makin, J. W., \& Matochik, J. A. (1986). Physical and behavioral sequelae of low birthweight in spiny mice (Acomys cahirinus). Developmental Psychobiology, 19, 463-472.

Porter, R. H., Matochik, J. A., \& Makin, J. W. (1983). Evidence of phenotype matching in spiny mice (Acomys cahirinus). Animal Behavior, 31, 978-984.

Porter, R. H., Matochik, J. A., \& Makin, J. W. (1984). The role of familiarity in the development of social preferences in spiny mice. Behavioral Processes, 9, 241-254.

Porter, R. H., Matochik, J. A., \& Makin, J. W. (1986). Discrimination between full-sibling spiny mice (Acomys cahirinus) by olfactory signatures. Animal Behavior, 34, 1182-1188.

Porter, R. H., McFadyen-Ketchum, S. A., \& King, G. A. (1989). Underlying bases of recognition signatures in spiny mice Acomys cahirinus. Animal Behavior, 37, 638-644.

Porter, R. H., Moore, J. D., \& White, D. M. (1981). Food sharing by sibling vs. nonsibling spiny mice (Acomys cahirinus). Behavioral Ecology \& Sociobiology, 8, 207-212.

PORTER, R. H., \& RUTTLE, K. (1975). The responses of one-day-old Acomys cahirinus pups to naturally occurring chemical stimuli. Zeitschrift für Tierpsychologie, 38, 154-162.

Porter, R. H., Sentell, S. W., \& Makin, J. W. (1987). Effects of intranasal $\mathrm{ZnSO}_{4}$ are mitigated by the presence of untreated littermates. Physiology \& Behavior, 40, 97-102.

Porter, R. H., Tepper, V. J., Baumeister, A. A., Cernoch, J. M., \& MATOCHIK, J. A. (1982). Interactions among unfamiliar spiny mouse (Acomys cahirinus) weanlings. Behavioral \& Neural Biology, 34, $190-200$.

Porter, R. H., Tepper, V. J., \& White, D. M. (1981). Experiential influences on the development of huddling preferences and "sibling" recognition in spiny mice. Developmental Psychobiology, 14, 375-382.

Porter, R. H., \& Treadway, J. T. (1974). Effects of previous exposure on olfactory discrimination in Acomys cahirinus. Nature, 249, 157-158.

PORTER, R. H., \& WYRICK, M. (1979). Sibling recognition in spiny mice (Acomys cahirinus): Influence of age and isolation. Animal Behavior, 27, 761-766.

Porter, R. H., Wyrick, M., \& Pankey, J. (1978). Sibling recognition in spiny mice (Acomys cahirinus). Behavioral Ecology \& Sociobiology, 3, 61-68.
Rabinovitch, A., Gutzeit, V., Grill, V., Kikuchi, M., Renold, A. E., \& Cerasi, E. (1975). Defective insulin secretion in the spiny mouse (Acomys cahirinus). Israeli Journal of Medical Science, 11, 730-737.

Rabinovitch, A., Gutzeit, A., Kikuchi, M., Cerasi, E., \& Renold, A. E. (1975). Defective early phase insulin release in perifused isolated pancreatic islets of spiny mice (Acomys cahirinus). Diabetologia, 11, 457-465.

Rabinovitch, A., Gutzeit, A., Renold, A. E., \& Cerasi, E. (1975). Insulin secretion in the spiny mouse (Acomys cahirinus): Dose and time kinetic studies with glucose in vivo and in vitro. Diabetes, 24 , 1094-1100.

RAFF, R. A., \& KAUfMAN, T. C. (1983). Embryos, genes, and evolution. New York: Macmillan.

SARICH, V. (1985). Rodent macromolecular systematics. In W. P. Luckett \& J.-L. Hartenberger (Eds.), Evolutionary relationships among rodents: Multidisciplinary analysis (pp. 423-452). New York: Plenum.

ShkolNik, A., \& BorUt, A. (1969). Temperature and water relations in two species of spiny mice (Acomys). Journal of Mammalogy, $\mathbf{5 0}$, 245-255.

Simpson, G. G. (1959). The nature and origin of supraspecific taxa. Cold Springs Harbor Symposia in Quantitative Biology, 24, 255-271.

STRASSER, H. (1968). A breeding program for spontaneously diabetic experimental animals: Psammomys obesus (sand rat) and Acomys cahirinus (spiny mouse). Laboratory Animal Care, 18, 328-338.

Szijarto, K., Coffee, R. J., Boyle, C., Bailey, D., Mulé, M., IACOVONE, E., \& DENI, R. (1985). Postpartum social interactions in families of spiny mice (Acomys cahirinus) observed in a laboratory environment. Bulletin of the Psychonomic Society, 23, 253-255.

Tessitore, C. T., \& BRUNJes, P. C. (1988). A comparative study of myelination in precocial and altricial murid rodents. Developmental Brain Research, 43, 139-147.

VESEY-FitZGERALD, D. F. (1966). The habits and habitats of small rodents in the Congo river catchment region of Zambia and Tanzania. Zoologica Africana, 2, 111-122.

WaHRMAN, J., \& ZAHAVI, A. (1953). Intra-generic differences in chromosome numbers of spiny mice (Rodentia: Murinae). Bulletin of the Research Council of Israel, 3, 265-266.

WEAVER, D. R., \& REPPERT, S. M. (1987). Maternal-fetal communications of circadian phase in a precocious rodent, the spiny mouse. American Journal of Physiology, 253, E401-E409.

WISE, P. H. (1977). Significance of anomalous thermoregulation in the pre-diabetic spiny mouse (Acomys cahirinus): Oxygen consumption and temperature regulation. Ajebak, 55, 463-473.

Young, D. A. B. (1976). Breeding and fertility of the Egyptian spiny mouse, Acomys cahirinus: Effect of different environments. Laboratory Animals, 10, 15-24.

ZAHAVI, A., \& WaHRMaN, J. (1956). Chromosome races in the genus Acomys (Rodentia: Murinae). Bulletin of the Research Council of Israel, 5, 316.

(Manuscript received January 12, 1990; revision accepted for publication March 7, 1990.) 